\title{
The Romance Publishing Industry and Its Reputation
}

\section{Lauren Cameron ${ }^{1}$}

Published online: 23 January 2020

(c) The Author(s) 2020

\begin{abstract}
Romance has always had a negative reputation, but is this reputation justified? This study examines the negative stigma surrounding the billion dollar romance publishing industry in the USA and UK. The potential causes are discussed, and testimonials from contemporary romance readers and writers provide a basis for the case that this judgemental stance should be removed.
\end{abstract}

Keywords Romance Fiction market $\cdot$ Perception of romance $\cdot$ Book community · Romance authors $\cdot$ Readers

\section{Introduction}

Romance fiction is one of the most popular fiction genres in the United Kingdom and the United States, but there is a stigma surrounding it. ${ }^{1}$ This stigma shames romance readers and writers, because society sees romance fiction as "trashy". ${ }^{2}$ This creates small communities of romance readers that support each other while often hiding their love of the books. Despite its reputation, it is a billion-dollar industry. ${ }^{3}$

Romance is an intrinsically feminine genre, which creates a problem in misogynistic societies that are attempting to police women's bodies and minds. ${ }^{4}$ The struggle to implement feminism is not just a problem within the UK and USA, but it is also holding back the romance community from being acknowledged as a legitimate section of fiction readers. The aims of this study are to discover how the negative perception of romance came about, and how it has changed throughout the history of the genre. The cultural influence of misogyny in the UK and USA will be examined

\footnotetext{
1 [14].

2 [24].

3 [14].

4 [24].

Lauren Cameron

laurencameron@live.ca

1 Edinburgh Napier University, 33 Calder Road, Edinburgh EH 11 3PF, UK
} 
in relation to the romance genre to determine whether patriarchal values have any influence on the negative stigma. ${ }^{5}$

Romance is a genre that is valuable and legitimate, and also not what most people believe it to be. Perception of romance has been heavily skewed by a select few novels. There are very few academic studies that positively reflect romance. With only negative voices present, it cannot be conclusively said that romance has no value. By presenting the other side of the argument, new information can be added to the academic study of the fiction market.

\section{Defining Romance}

Romance is a subgenre in fiction that must contain two main components: a central love story, and an emotionally satisfying ending. ${ }^{6}$ In the US alone, romance is a billion dollar industry. ${ }^{7}$ Within this genre, there are further subgenres: historical, erotica, etc. For the purpose of this study, contemporary romance will be the focus. Contemporary romance must meet the basic qualifications of romance, while also being a reflection of the time period it is written in. ${ }^{8}$ Typically, contemporary romances include any romance set in the time period it is being written, within 50 years. ${ }^{9}$

All romance novels that were once contemporary but now considered historical provide insight into the state of romance throughout its history. Today's contemporary romance is focused on two things: bodily autonomy, and a push towards diversity. ${ }^{10}$ Early romance novels saw heterosexual white women defying social norms, overcoming personal struggles, and finding happiness, a theme that has continued today with much more diversity. ${ }^{11}$

Terms used to describe romance novels are often problematic and used to keep romance contained in a box. ${ }^{12}$ By calling a book an "easy-read", it implies that the readers of the genre are not intelligent. "Porn" implies that readers only read the novels for sexual reasons; to categorize every romance novel as an outlet for sexual frustration diminishes the genre and women. ${ }^{13}$ Finally, "trash" implies that the novels are bad, when the entire point of romance is to examine human relationships. ${ }^{14}$

The first novel considered a romance was Pamela; or Virtue Rewarded, by Samuel Richardson. ${ }^{15}$ Published in 1740, it was the first novel to be written solely from the female point of view, and to feature a love story with a "happily ever after". ${ }^{16}$

\footnotetext{
5 [13].

6 [16].

7 [22].

8 [21].

9 [21].

10 [1].

11 [16]

12 [25].

13 [25].

14 [18].

15 [7].

16 [7].
} 
Writers such as Jane Austen and Charlotte Brontë published successful romance novels, but the genre did not take off as a mass market industry until the 1930s, with the founding of Harlequin. ${ }^{17}$ It was the first company to change with the romance genre; selling romance novels was about convenience for women, which was a business plan that allowed them to become a powerhouse in a multi-billion-dollar industry. ${ }^{18}$ Today, the romance audience is $82 \%$ female, with $92 \%$ reading print, $64 \%$ eBooks, and 35\% audio books. Romance publishers have kept up every step of the way, allowing them to maintain $23 \%$ of the USA book market. ${ }^{19}$

Modern romance is thought to have begun in 1972, with the publication of The Flame and the Flower by Kathleen E. Woodiwiss. ${ }^{20}$ This was the first romance novel to contain an explicit sex scene, which then launched a trend in romance that continues to this day. ${ }^{21}$ However, it also contained problematic content. ${ }^{22}$ This novel had many explicit rape scenes, as did its contemporaries, which was a huge problem from the elevated perspective of the twenty-first century. ${ }^{23}$ However, in 1972 , women in the UK and the USA could not get a credit card, and marital rape was not considered a crime. ${ }^{24}$ Idealized and glamourized explicit rape as a plot device has since been eradicated from the genre, but as we can see with the current \#MeToo movement, our society has not had the same revelation. ${ }^{25}$

The heroes in romance reflect the sociopolitical times. For example, with the economic crash of the early $2000 \mathrm{~s}$, romance saw a rise in billionaire heroes. ${ }^{26}$ Now, with feminism strengthening and the rise of \#MeToo and the current political climate, the alpha male hero no longer works alongside the strong female heroine. ${ }^{27}$ Contemporary romance novels reflect the times they are written in, and these novels have drastically changed from the versions released in 1972.

\section{The Issue}

Romance, as a genre, has been ridiculed by larger society since its advent. Despite consistently being a best-selling genre and billion-dollar industry, romance still receives little to no respect. Author Penny Reid states that she has seen her books called "trashy romance", "fluffy", "smut". ${ }^{28}$ In a 2019 article about upcoming 
novels, Cosmopolitan called a romance novel "too well written to be considered romance". ${ }^{29}$ This insults the writers and readers of the genre.

One of the most recent instance of romance shaming that renewed the debate had to do with author and politician Stacy Abrams. ${ }^{30}$ Abrams is a bestselling romance novelist. She went on the Stephen Colbert show to discuss her political career. Instead, Colbert got out one of her novels, which Abrams politely admitted to writing. Abrams was clearly uncomfortable with the direction the conversation was going, because Colbert's tone and the tone of the audience were ridiculing. Colbert then proceeded to read one of the sex scenes in her novel, to her obvious discomfort, and then laughed. ${ }^{31}$ Abrams was being shamed for being a successful author. Abrams is so much more than her romance career, and to out something she clearly prefers to keep private insults her and the genre.

\section{The Debate}

The debate about whether romance is a worthy genre goes back to its advent. Not just romance, but women's writing as a whole. Because romance is a female dominated genre, it is seen as more lowbrow than almost any other genre. Despite being a female dominated field, romance receives just as much backlash from women as it does from men. In 1856, George Eliot described women's writing as "frothy, prosy, pious, and pedantic. However, there was another perspective as well, otherwise women's writing would not have survived. Virginia Woolf said: "[...] the values of women differ very often from the values which have been made by the other sex; [...]. Yet it is the masculine values that prevail. [...] This is an important book, the critic assumes, because it deals with war. This is an insignificant book because it deals with the feelings of women in a drawingroom". ${ }^{32}$ Woolf correctly identified the main problem with romance: it deals with women's feelings.

\section{What Academics are Saying}

The differing opinions on romances worthiness as a genre come from those who read it, and those who do not. Those within the community make convincing arguments for why it is worthy. However, most pieces written on romance in the past 20 years were not written by people who read the genre, and therefore do not offer a full perspective, or a positive one.

Hannah Eisley Burnett argues that the shame surrounding romance draws its readers together into a community. ${ }^{33}$ Eisler-Burnett's thoughts are that romance

\footnotetext{
29 [23].

30 [15].

31 [15].

32 [4].

33 [5].
} 
would sell even more incredibly if it was not so highly ridiculed by society as a whole. ${ }^{34}$ By building a community of romance readers, the shame associated with reading it loses power and disappears. ${ }^{35}$

Sarah Wendell argues that it is a genre focused on emotional development and self-actualization, that values women's emotions and desires. ${ }^{36}$ Jennifer Weiner agrees, and she thinks that these books are so criticized because they are about women. Weiner say, "It's sexist when critics automatically relegate anything concerning young women's lives to the beach-trash Dumpster bin-especially when they're automatically elevating anything about young men's lives to the exalted spheres of Literature". 37

The fact that readers continue to read the genre despite the shame placed upon them shows that the genre is interesting and worthy. ${ }^{38}$ Pamela Regis argues that romance is the most popular genre, but popularity does not equal acceptance. ${ }^{39}$ Critics characterize the genre from a few reviewed texts, which are gate-kept by men. ${ }^{40}$ Nora Roberts has written and published over 200 novels, but her books have only been reviewed by the New York Times twice, despite consistently being best-sellers. ${ }^{41}$ A reader's rejection is based on personal taste, whereas a critic's opinion is meant to be based on "reasoning and sufficient evidence", and the majority clearly are not. $^{42}$

Critical rejection of romance novels began to emerge in the 1960s, alongside firstwave feminism. ${ }^{43}$ Germaine Greer said, "romance nourishes disappointed women, creates unattainable fantasy, and is cause and effect of women's oppression". ${ }^{44}$ Feminists in this time did not like how passive women were, but Regis argues that this is a deliberate misreading of the genre. ${ }^{45}$ Just because a woman's story has a love story, does not mean that the woman is passive; the novels try to reaffirm women's independence by giving them choice in their own happiness. ${ }^{46}$ Krentz argues that romance novels are subversive, because they show a woman holding power but not abusing it. ${ }^{47}$

Krentz, Wendall and Regis are some of the only academic voices advocating for romance. The other voices are much more negative, such as an article that claims the idealized versions of love that romance presents lead to psychosexual 
problems, perpetuates gender roles and does not demonstrate safe sex practices. ${ }^{48}$ Jade Deveraux argues back that "Supposedly women who read [romantic novels] are so stupid that they can't tell a story from reality. Is anyone worried that the men who read spy thrillers are going to go after their neighbours with an automatic weapon?". 49 Deveraux's point demonstrates that Iqbal's point is about policing women's minds and bodies. As well, contemporary romance novels have adapted to keep up with reliable contraception and consent. ${ }^{50}$

\section{Is Romance Feminist?}

In her study, Linda Christian-Smith argues that romance novels are anti-feminist because men give meaning to the women. ${ }^{51}$ But do the women in the novels not also "complete" the men? The story is meant to be focused on them finding love, not the other aspects of their lives, because that is not the genre. The couples, whether men and women, men and men, or women and women, complement each other, and choose to live their lives together.

Christian-Smith did a study of 30 girls at a lower middle-class school to see the effects of reading romance on teenagers. According to her, girls read romance for four main reasons: to escape, entertainment, because they enjoy it, and to learn about love. ${ }^{52}$ Christian-Smith argues that romance novels are the reason girls are getting in trouble in school, and that these young girls are failing their classes because they read romance. ${ }^{53}$ However, the girls were women of colour in a low income area who are not given as many choices in society. Perhaps the most concerning idea of Christian-Smiths' was that girls only get part-time jobs to be consumers, and put themselves in situations where they may have a romantic encounter. ${ }^{54}$

In direct contrast to Christian-Smith's ideas, Drew Himmelstein says, "reading romantic novels is a useful way for teenagers to learn about relationships and experiment with their sexual imaginations in a safe space. At a time when adolescents are developing the neural pathways for sexual pleasure and fantasy that will carry them into their adult lives, stories and characters provide a vivid world that is both "titillating and educational". ${ }^{55}$ By allowing teenagers to learn about sex and romantic situations from romance novels, they view is less as a forbidden thing, but a way to connect with another person, and are therefore more likely to have respect for their own bodies and sex itself. ${ }^{56}$ Romance novels teach girls to be a part of a sexual relationship, not just an accessory. ${ }^{57}$

\footnotetext{
48 [10].

${ }^{49}[10]$.

${ }^{50}[16]$.

${ }^{51}[3]$

$52[3,176]$

53 [3].

$54[3,183]$.

55 [8].

$56[8]$.

${ }^{57}$ [8].
} 
Christian-Smith's ideas would reflect that romance is not feminist. However, she has never been immersed in the genre. No one is saying that romance novels all represent feminist values; author Courtney Milan argues that romance is not inherently a feminist genre, but it is changing to become so. ${ }^{58}$ Romance explores what it is to be a woman, and draws feminists because there are so many women in the business. ${ }^{59}$ These feminists are making sure women are represented and empowered with the books they read. ${ }^{60}$

As well, romance is feminist because it welcomes women from all over the world to explore and talk about books that they love. ${ }^{61}$ Romance and its adaptation and ability to explore new issues and diversity make it unique. ${ }^{62}$ Romance as a genre has room for critiquing, as all genres do, but it needs to be informed critique based on actual evidence. ${ }^{63}$

\section{The Romance Formula}

The other main point of contention about romance is that the books follow a "formula". ${ }^{64}$ This is true; a romance novel needs an emotionally satisfying ending, and it has to have a love story. Typically, the first sex scene will occur $60 \%$ of the way through the story, followed by a fall out between the hero and heroine, and then a reconciliation. ${ }^{65}$ However, how the characters get there varies in thousands of different ways. Krentz argues that crime, which is seen as a more literary genre, also follows a formula: there is a crime, there is someone trying to solve it, there is a conflict, the false suspect, and then the true criminal. ${ }^{66}$ Yet crime is not seen negatively, because it is a male dominated genre. ${ }^{67}$ This shows that it is the women that are the issue, not the formula.

\section{Reader Experience}

Thanks to sites like Amazon and the increasing numbers of self-published authors, US and UK romance novels are accessible all over the world, creating communities. The shame surrounding romance forces readers to rely on others and creates the idea that romance should be a reader's "dirty little secret" ${ }^{68}$ Many readers do keep the

\footnotetext{
${ }^{58}[13]$.

${ }^{59}[13]$.

${ }^{60}[13]$.

${ }^{61}[25]$.

${ }^{62}[20]$.

${ }^{63}$ [18].

${ }^{64}$ [2].

65 [5].

${ }^{66}$ [11].

${ }^{67}$ [11].

${ }^{68}$ [5].
} 
books they read a secret if it is romance, because of one too many negative interactions or shared experiences that shame them into hiding.

Three Facebook romance book club groups were interviewed, totaling 14,730 members, with 74 members choosing to participate. The first group was Kennedy Ryan Books, a book club dedicated to diverse romance, with 6598 members at the time of the interview and 17 responses. The second group was Krista and Becca Ritchie's Fizzle Force, dedicated to general contemporary and LGBTQ+ romance, with 4224 members and 11 responses. The final group, Mariana Zapata's Slow Burners, focused on contemporary romance with a "slow burn" (the characters do not become a couple until $70 \%$ through the novel) with 3908 members, and 40 responses. Finally, 6 participants chose to remain anonymous.

All participants were aware of a stigma and negativity or judgement surrounding the romance genre, even if they had not experienced it themselves. Their differing reactions to this judgement can be attributed to human character and outlying factors. Though not all participants experienced the stigma in the same way, all were aware of a negativity surrounding romance as a genre, but stated that this would not prevent them from reading the books that they enjoyed.

All of the participants were female; this was expected, as romance is a female dominated genre, and those men that had the opportunity to participate declined. Since romance is targeted mainly towards women, having all female responses does not limit the scope of this study. The female respondents represented various demographics: married, single, white, BAME, LGBTQ+, teenagers, adults, etc. The majority of participants were highly educated, with at least a college degree. This counters Christian-Smith's argument that reading romance is the reason young girls are doing poorly in school. ${ }^{69}$ As well, people generally think that romance readers are "undereducated, overweight, undersexed", but this reader data shows that is not true. $^{70}$

Of the 74 people who responded, $48 \%$ got overly negative reactions when they say they read romance, $13 \%$ said they got strictly positive reactions, and $39 \%$ stated that they received a mix of the two. Of these same responses, $64 \%$ said that they were very open about their love of reading romance, $29 \%$ said they kept it a secret from those in their "real life", and 7\% did not have applicable responses. Since only $13 \%$ of readers received positive reinforcement for reading romance, it is surprising that the majority of romance readers do not hide it, when they are more likely to get a negative reaction. This shows that since Eisler-Burnett's publication, there seems to have been a shift in the shame women feel about reading romance. Women no longer let the shame control them and are much more open about their love of the genre, despite the risk of being shamed for it. The shame has not gone away, but the control it holds has.

Readers feel shame attempting to be forced upon them for reading romance, either by those close to them, online and in the media, or complete strangers. Despite this, many either seek out communities, keep it a secret, or share their love for the genre.

\footnotetext{
${ }^{69}[3]$.

${ }^{70}$ [25].
} 
The differences in the readers who felt comfortable and those who did not seem to have a personal factor. Some readers stated that it was their age that had made them more comfortable with being open about their reading. Younger readers tended to keep their interest in romance to themselves for fear of parental backlash.

Some common themes that appeared throughout reader responses were where the shame they felt came from; there was not one single participant that denied that the shame existed. Everyone agreed that society had to do with the shame they felt, even if they had not personally had a negative interaction. Most respondents who had had a negative interaction stated that it came from someone they knew, or someone within their community. One reader stated that whenever one of her friends sees a book with a two-star or lower review, he states that it would be a book she would like, because she likes "trash". Several women also echoed that men were the ones to comment negatively on their reading choices; one woman stated that her uncle routinely makes her uncomfortable about reading romance, sexualizing the books.

Several women raised an interesting point: their husbands are the only ones in their lives threatened by them reading of romance novels. They feel threatened by the male characters in the books; one woman said her reading of romance contributed to her divorce. Not all husbands were like this; another woman attributes her love of romance and her husband's support of it to their 40-year relationship. However, this echoes Wendell's idea that men feel that romance readers will not be able to tell fiction from reality, and reinforces her idea that women can, in fact, tell the difference. $^{71}$

Readers who discovered the genre at the recommendation of someone in their lives were typically more open about their love of romance, whereas women who had discovered the genre on their own kept it a secret from those in their "real life", because they do not have the support needed to combat the shame being forced upon them as a genre. Many respondents said that discovering romance was a source of happiness, which reflects the idea that romance is an escape into a world where women do have a voice.

\section{Author Experience}

Six authors completed the interview. Jessie Edwards was interviewed for her role within the RWA. Elizabeth May was contacted because she writes both romance and sci-fi, as well as fantasy. Elle Kennedy is a self-published author, who also writes LGBTQ+ romance. Kennedy Ryan writes BAME and diverse romance. Rebekah Weatherspoon writes BAME and LGBTQ+ romance. Samantha Young and Sarah Maclean are traditionally published authors. Susannah Nix is self-published and focuses on romance featuring heroines in STEM. Tessa Dare is a best-seller, and one of the most well-known names in romance. Finally, Adriana Anders is an author who reached out after seeing the reader interview questions, and she is an awardwinning romance author. The questions asked centered around the authors' romance

71 [24]. 
careers, the reactions they get to their profession, and why they write romance. Edwards received a list of questions about the RWA and its purpose within the romance community.

When asked about common misconceptions they receive, the authors all had very similar responses. $40 \%$ said that the most common misconception they received was that romance was for unintelligent or lonely women. $40 \%$ said that people generally thought their books were "porn", and $20 \%$ said that people commonly thought that their books were unrealistic. Most authors negative interactions came from their books being referred to as "porn". Anders argues that this is false and reductionist, because romance does not have to contain sex scenes. Nix's romances are "closed door" because they do not contain explicit sex scenes. Anders argued, "can you imagine if we referred to all thrillers as violence-porn?" This would not happen, because it reduces the genre to one element. As well, she argues that a sci-fi novel written by a man "riddled with explicit, poorly-written sex scenes gets positive attention, when romantic fiction gets an eyeroll", simply because it is written by a women, which is the root of the problem.

Most of the authors had mostly positive interactions when they said they write romance, with a few small negative interactions. The negative interactions typically came from twitter "trolls" who had not actually read their books, or from people they knew in real life reducing their careers to "fluff". The authors felt that these terms reduced the hard work that went into writing and producing their books. Rebekah Weatherspoon said that she was careful to surround herself with supportive people, which helps to block out the negativity that she might otherwise receive.

Nix, Kennedy and Young all stated that they began writing in other genres before moving into romance. Even today, Young says that her romance is more focused on the psychological aspects of romantic relationships. Nix chose to take her scientific knowledge and bring it to romance by exploring women in STEM in romantic relationships. Kennedy chose to move from thrillers to romance, often combining the two genres, because she loves the happily ever after aspect of romance.

Kennedy and Anders both stated that the romance community was full of some of the most intelligent men and women that they have ever met, so to see it reduced to "fluff" or "porn" is disheartening. All of the authors interviews had the utmost respect for their readers, so the view that they are anything less than intelligent, diverse human beings is an idea that comes from outside of the community; the same place that judges romance novels as lowbrow. They describe the romance community as "unique", "tight-knit" and "inclusive", and say that they have never experienced something like it with any other book genre, something that was echoed by the reader responses.

The romance community has a formal community, known as the Romance Writers of America. This group is a collection of romance authors who support each other, and Jessie Edwards says that "Romance authors are the most active, engaged, and unified community". They use their platform to talk about feminism, diversity and politics, and to stay in touch with their readers, moreso than any other genre. Edwards also pointed out that romance is at the forefront of publishing innovation, thanks to the community that surrounds and supports it. From online self-publishing to reader interaction, if publishing adapts a trend, romance did it first. The power of 
the romance community is so strong that it can change the entire publishing community, and yet it is still underestimated.

\section{Findings}

The academics referenced studied romance and its effect on society, but very few study its reputation. Much of the literature available about romance is very negative and one sided, with the positive voices featured some of the only ones available. The negative voices are often unsubstantiated and heavily influenced by the societal stigma surrounding romance, rather than actually fact. The positive data is often written by academics within the romance community, which again further reflects the idea of romance readers enjoying the genre while those outside of the community disparaging it.

The results of all of the interviews conclude that there is shame surrounding the romance fiction community. Several respondents offered theories of why this could be; one woman attributed it to Fifty Shades of Grey by E. L. James and the negative attention it brought to the romance community. However, most of the readers had been reading romance and feeling the shame surrounding it decades before the publication of Fifty Shades. The common denominator seems to point to romance being a female dominated genre, meant for women, contributing to feminism, and therefore it is an enemy of the patriarchy. These reader comments echo what academics who support the romance genre have found; romance is seen as less because it values and supports women. ${ }^{72}$

Romance is a genre about women taking control of their bodies; female readers can see themselves in the characters they read about, and that is empowering. ${ }^{73}$ Girls are conditioned to search for love from a young age, while men are not, which creates a disconnect in society. ${ }^{74}$ By reading romance, girls and women can fulfill the need for love that society has forced upon them, without the disappointment that men in real life often provide when compared to the princes girls are taught to look for. ${ }^{75}$ Most women agreed that what they are reading is not reality, but they want to read romance anyway, because it brings them happiness.

To elevate books targeted towards men over those about women is sexist. ${ }^{76}$ The patriarchy places men above women, and so often women's interests are demeaned in order to keep this social order. Is romance demeaned because it is actually not well written, or because it appeals mainly to women? Considering some of the classical canon today is romance, signs point to the shame surrounding romance being another way to police women's bodies and minds. Jane Austen, Charlotte and Emily Brontë all wrote romance that is worshipped today, and yet our contemporary

\footnotetext{
72 [24].

$73[24,6]$.

74 [18].

75 [9].

76 [4].
} 
romance authors are demeaned and looked down upon. ${ }^{77}$ Just because something is written by women, for women, does not mean that it should be relegated to a lesser tier.

Further proof of the negativity surrounding romance having to do with women and not the actual book content is evident when you compare it to crime fiction. Crime is a typically male dominated genre and is heralded as one of the best in fiction. However, it follows a formula, it contains adult content, and is a best-selling genre, just as romance is. ${ }^{78}$ The only differences between these genres is that one is targeted towards men, whereas the other is targeted towards women. If crime can be lauded as a highbrow fiction genre, how can we classify all romance as lowbrow? There is bad romance just as there is bad crime fiction, but both genres also have stand-out exceptional work.

The fourth best-selling fiction author of all time is Danielle Steel. She is the bestselling fiction author currently alive, having written 179 books. ${ }^{79}$ The fact that she is one of the best-selling authors of all time should be enough to elevate the genre, and yet it is still seen as less because she is a woman, and because women are the ones that typically buy her books. In contrast, Nicholas Sparks is a male author often heralded for writing romance, despite the fact that he does not. His books are general fiction, because they do not contain an emotionally satisfying ending, one of the two main criteria ${ }^{80}$ Despite this, he still gets labelled as a romance author and praised for writing it. He does not like the label romance, because he believes the books he writes has more "depth" than romance, and he does not like the genre. ${ }^{81}$ This problem is two-fold: it is a man demeaning romance and objecting to being associated with it, and it is also a man being heralded as a wonderful romance writer, while the woman who is the best-selling fiction author currently alive is still seen as less for writing romance. One reader had a particular stand out response that contributed to the theory that misogyny is the reason romance gets a bad reputation. She was recently in line at a bookstore, and two elderly women in front of her stated that they would never buy a book written by a woman. There is still an idea in society that books written by men are better, and while this idea is still present there is no way for romance to thrive.

Despite the negative patriarchal influence on romance, the romance community is thriving within itself. This community is mainly online, in places like Goodreads or Facebook book groups. However, some women stated that they went so far as to make separate Facebook and Goodreads accounts so that people from their "real life" would not know about their love of romance. Others stated that they were lucky enough to have support, which made them feel comfortable enough to share their love of the genre.

\begin{tabular}{ll}
\hline 77 & {$[16]$.} \\
78 & {$[11]$.} \\
79 & {$[12]$.} \\
80 & {$[21]$.} \\
81 & {$[19]$.}
\end{tabular} 
One of the main complaints academics have against romance as a genre is that it is not "feminist". However, like any genre, it has been growing and changing. To say that today's romance is completely un-feminist is reductive. Almost all contemporary romance novels display bodily anatomy and women making their own choices when it comes to sex, something larger society has still not been able to do, despite the advances in feminism. Anders described romance as "subversive feminist literature", because it is "a genre written primarily by women, for women, and about women" who are looking for "personal, emotional and physical fulfilment". Contemporary romance covers all sorts of feminist topics, from discrimination in the workplace to abortion, so to write is off as "fluff" or "trash" when it has so much to offer and teach on these subjects is harmful to the feminist movement.

As well, academics are once again diminishing female intelligence. As has been established, women know how to tell the difference between fiction and reality. Along those lines, they are also able to tell what is feminist and what is not. If they do happen to read a romance novel without a strong, feminist main character, they can still be a feminist. Feminism is not a static state, but one that is ever changing and growing as society does, just like romance. Weatherspoon pointed out in her interview that her writing changes with the political and social climate, because she is learning more every day. Romance and feminism have grown together.

Romance is intrinsically feminist, because it gives a voice to women to write about the female experience. ${ }^{82}$ Romance novels contain stories of women reaching their dreams with the support of those around them and finding love in addition to that. For some women, finding love and starting a family is their goal, and feminism is supposed to be about giving women a choice; if that choice is to get married, it needs to be respected, otherwise the foundations of feminism fall apart.

Romance, as a genre, deserves more recognition within the fiction market. Libraries and bookstores need to have a more prominent display and selection of romance novels for readers to see and to generate interest. Many bookstores do not have romance specific sections but will have a crime section on prominent display. By adding a specific romance section, romance is validated. Romance is a genre that is mainly online, and this is something that needs to change in order for romance to be seen as a valid.

Readers also need to combat the personal shame they feel. As the reader interviews indicate, many readers have already begun to do this by being open about the fact that they read romance. If readers, personally, do not feel shame about reading and enjoying romance, then the negative judgment from outsiders becomes moot. Even if it is only being open about it online, it is still a small step in the direction of a genre that is dedicated to women being accepted by society as a whole. If readers do not let themselves be shamed, they cannot be shamed, and the oppressive voices lose their value.

Words like "fluff" and "trash" need to be taken out of the vernacular surrounding romance. They diminish the intelligence of writers and readers. No explanation or justification is needed for reading romance, because readers should be able to enjoy

${ }^{82}[13]$. 
a genre they love. Romance readers are smart, diverse, often educated women who just want to be able to read without societal commentary on their intelligence. A book does not need to be on a short list for a literary award to be worthwhile, and the idea that only books with that potential should be read is harmful to the readers and authors who truly love the genre. The necessary happy ending is what people love about it, and is a poor excuse for demeaning the genre; no one truly has issue with a book ending happily, it is just one of many reasons that people use to hide less acceptable objections. ${ }^{83}$ The main reason that people do not accept romance is because it is a genre targeted at women, showing them having control of their bodies and minds. ${ }^{84}$

In the USA, laws are being passed in 2019 to control women's bodies. ${ }^{85}$ When that is considered, it is easy to see that the same voices that want to repress women's voices would also want to eradicate a genre that promotes these very things. Reader responses showed that the negative judgment they received came from a few spaces: the men in their lives, conservative and religious friends, the same voices attempting to make laws and set limitations on what women can do. ${ }^{86}$ Not all members of these communities think this way, but there are some voices outnumbering the others.

The misogyny surrounding the genre can be seen in countless places: husbands believing their wives cannot tell the difference between the fiction and reality, Stacey Abrams being mocked for writing romance, romance authors being told their work is "trash". ${ }^{87}$ Romance has been fighting to survive against misogyny since its advent, and the common result is that is has thrived. People argue that it is too formulaic, but other similar fiction genres receive no backlash, proving that this is not the true problem. ${ }^{88}$ It is a genre that promotes women's voices, and for that reason should be at least given consideration for true equality. ${ }^{89}$ Romance is not for everyone, just like any other genre. However, no other genre is continuously mocked by those that do not read it. This is not just a fiction market issue; it reflects the larger issues of misogyny in UK and US society, something that needs to be improved in all areas so that women can make their own choices about their bodies, careers, and reading. Romance deserves a better reputation.

Open Access This article is licensed under a Creative Commons Attribution 4.0 International License, which permits use, sharing, adaptation, distribution and reproduction in any medium or format, as long as you give appropriate credit to the original author(s) and the source, provide a link to the Creative Commons licence, and indicate if changes were made. The images or other third party material in this article are included in the article's Creative Commons licence, unless indicated otherwise in a credit line to the material. If material is not included in the article's Creative Commons licence and your intended use is not permitted by statutory regulation or exceeds the permitted use, you will need to obtain permission

${ }_{83}^{83}[18]$.
84 [11].
85 [26].
${ }^{86}[26]$.
${ }^{87}[15]$.
${ }^{88}[11]$.
${ }^{89}[13]$. 
directly from the copyright holder. To view a copy of this licence, visit http://creativecommons.org/licen ses/by/4.0/.

\section{References}

1. Billings, L, Christina H. Writing Romance Novels Is a Feminist Act.” Time, March 20, 2017. https ://time.com/4718350/romance-novels-are-feminist/.

2. Chelton MK. Searching for birth parents or adopted children: finding without seeking in romance novels. Reference and User Services Quarterly. 2018;57(4):266-73.

3. Christian-Smith L. Voices of resistance: young women readers of romance fiction. In: Weis Lois, editor. Beyond silenced voices: class, race and gender in United States Schools. New York: State University of New York Press; 1993.

4. Davis-Kahl S. The case for chick lit in academic libraries. Collection Building. 2008;27(1):18-21.

5. Eisler-Burnett Hannah. Shame game: romance novels and feminist shames, a mad lib for collective feeling. Women and Performance: A Journal of Feminist Theory. 2018;23(1):140-4.

6. Flood, A. 'Women are having different fantasies': romantic fiction in the age of Trump. The Guardian, March 8, 2018. https://www.theguardian.com/books/2018/mar/08/women-are-having-differentfantasies-romantic-fiction-in-the-age-of-trump?fbclid=IwAR1stHOVW6F7Fjvzd7BZWwH7uvXK zkMKAbD0-8_fFBkIV5Y-61Or0k8AY_8.

7. Harris, M. The history of the romance novel. Tribune, February 16, 2017. https://www.ericksonli ving.com/tribune/articles/2017/02/history-romance-novel.

8. Himmelstein, D. Sexy novels are good for your teenager's brain and body. Daily Beast, July 10 , 2019. https://www.thedailybeast.com/sexy-novels-are-good-for-your-teenagers-brain-and-body.

9. Hopkins Lisa. After Austen. London: Palgrave Macmillan; 2018.

10. Iqbal K. The impact of romance novels on women's sexual and reproductive health. J Fam Plann Reprod Health Care. 2014;40:300-2.

11. Krentz JA. Dangerous men and adventurous women. Pennsylvania: University of Pennsylvania Press; 1992.

12. Leach, S. How the hell has Danielle steel managed to write 179 books?" Glamour, May 9, 2019. https://www.glamour.com/story/danielle-steel-books-interview.

13. Luther, J. Courtney Milan on feminism and the romance novel. Shondaland, February 27, 2019. https://www.shondaland.com/inspire/books/a16752742/courtney-milan-on-feminism-and-theromance-novel/.

14. Mohammed, F. The business of the romance novel. Jstor Daily, February 11, 2019. https://daily.jstor .org/the-business-of-the-romance-novel/.

15. Moran, L. Stephen colbert flusters stacey abrams by reading her own romantic fiction. Huffington Post, April 4, 2019. www.huffingtonpost.com/abrams.

16. Pagan, A. A brief history of the romance novel. New York Public Library, February 15, 2018. https ://www.nypl.org/blog/2019/02/15/brief-history-romance-novel-recommendations.

17. Penny Reid. I've seen my books called.... Twitter, June 3, 2019. https://twitter.com/ReidRomance/ status/1135615107591892993.

18. Regis Pamela. A natural history of the romance novel. Pennsylvania: University of Pennsylvania; 2003.

19. Rivera, J. Sparks explains his process and why he hates the label 'romance'. MediaBistro, 2018. https://www.mediabistro.com/interviews/so-what-do-you-do-nicholas-sparks-bestselling-romancenovelist/. Accessed 8 June 2019.

20. Rockett, D. Resistance in romance. Chicago Tribune, 2017. http://digitaledition.chicagotribune. com/tribune/article_popover.aspx?guid=0b2772ff-eafb-4993-b6f9-4bac66a2fc59. Accessed 2 June 2019.

21. RWA. About the romance genre. Romance Writers of America; 2018. https://www.rwa.org/ Online/Resources/About_Romance_Fiction/Online/Romance_Genre/About_Romance_Genre .aspx?hkey=dc7b967d-d1eb-4101-bb3f-a6cc936b5219.

22. Sutherland J. You can judge a person by their book covers. Guardian Features Pages. 2005;2:113.

23. Warner, K., Sabrina, R.W. 29 Legitimately good erotic novels you must read. Cosmopolitian, February 27, 2019. https://www.cosmopolitan.com/entertainment/books/a36506/erotic-novel 
s-you-must-read/?utm_source=twitter\&utm_medium=social-media\&src=socialflowTW\&utm_ campaign=socialflowTWCOS.

24. Wendell S. Everything I know about love I learned from romance novels. Naperville: Sourcebooks Casablanca; 2011.

25. Wendell S, Tan C. Beyond heaving bosoms: the smart bitches' guide to romance novels. New York: Touchstone; 2009.

26. Wright, J. Women who miscarry could be criminally investigated under Georgia's new abortion law. Harper's Baazar. 2019. https://www.harpersbazaar.com/culture/politics/a27454956/what-does-georg ias-abortion-law-mean-women-who-miscarry/. Accessed 28 July 2019.

Publisher's Note Springer Nature remains neutral with regard to jurisdictional claims in published maps and institutional affiliations. 